\title{
The Journey to Revival: Thriving Revolutionary Batik Design and Its Potential in Contemporary Lifestyle and Fashion
}

\author{
Stephen T.F. Poon \\ Taylor's University \\ Malaysia
}

\begin{abstract}
Malaysian batik has permutated from a traditionalist position as a communal craft to becoming a brand identity feature of the nation. This paper provides in-depth understanding of the factors which have enabled the traditional batik craft sector to experience a popularity revival, despite perceived threats from mass-produced products. A review traces the evolution of batik through its roots, traditional elements and processes, followed by a discussion of the importance of this art form through examining the uses of Malaysian batik within the context of contemporary lifestyles. Batik's aesthetic, cultural and socioeconomic values will be examined to understand how they play a role in successfully revolutionising the local batik industry. Indubitably, the re-emergence of batik as an aesthetic and commercial art form has resulted from the market conditions of supply and demand. Through a questionnaire survey of local respondents and an interview, this research uncovered the perceptions and potential of batik art and design in contemporary lifestyles. Research findings demonstrated that public perceptions of its aesthetic value and versatile functionality were positive, and that inclusion of batik design into education as well media communication channels would improve its brand positioning. Interest could be stimulated through promotion on various media platforms. Cultural preservation was critical from the industry's perspective, and qualitative analysis found that current mass production of batik wear and modern furnishings to accommodate the needs of contemporary fashion must be balanced with continued, cohesive efforts to create brand awareness of the craft, to enhance brand loyalty towards Malaysian batik.
\end{abstract}

Keywords: batik artist, design, craft, contemporary lifestyle, brand

\section{INTRODUCTION}

The age-old art of batik spread with considerable global success to as far as East Turkestan (Persia), West Africa and India, a fact attributable to centuries of maritime trade which established routes of good exchange from inland and coastal regions of Southeast Asia [1]. Many heritage researchers today believe these inter-regional maritime goods trading and transportation systems have contributed greatly to the evolution, diffusion, sharing and exchange of techniques, patterns and influences for the decorative motifs of batik that particularise and define the region's cultural composites in terms of its cultural, spiritual and social significance [2].

The domestic batik industry comprises chiefly of small and medium-sized firms, using low to medium levels of production technology, with low entrepreneurial orientation, making the performers and contributors susceptible to competition from cheaper imitation and imported goods [3]. Nevertheless, batik's soft power contribution can be seen through its appeal that transcends cultural and socioeconomic barriers, since it is to the government's interest to incorporate and promote this tangible material culture as a national heritage symbol [4: 106].

\subsection{Objectives of Research and Hypotheses}

The objectives of this study are:

- To study the historical origins and investigate the evolution of Malaysian batik from traditional to the present;

- To discuss the associations between Malaysian batik design and contemporary lifestyles;

- To understand the aesthetic, cultural and socioeconomic values accorded to contemporary batik that has successfully revolutionised the batik industry in Malaysia. 
Research conducted via sequential explanatory mixed methods enabled the collection of primary data. A questionnaire was designed to survey 100 samples of respondents. The purpose of the survey was to measure the level of awareness towards, and acceptance of, Malaysian batik.

To further gain insights, direct engagement with practitioners was sought, and one participant from the local industry agreed to be interviewed. This approach is essential to validate the survey findings and thus, improve study accuracy. The following hypotheses were developed to frame the research argument:

Hypothesis 1: The incorporation of Malaysian Batik into contemporary fashion or products can increase and stimulate interest among consumers.

Hypothesis 2: Consistent branding of Malaysian Batik through online media and other interactive communication platforms stimulate consumer interest and engenders loyalty.

\subsection{Research Questions}

This paper examines the aesthetic, cultural and socioeconomic values of batik as drivers for revolutionising the local industry. Framing the study are two key questions:

- How did initial stages of Malaysian batik evolve towards current contemporary image?

- What is the association between Malaysian batik designs with contemporary lifestyle?

\section{LiTERATURE REVIEW}

Batik in general refers to the art of fabric dyeing (Figure 1); by utilising the wax resist technique [5]. Studies investigating the evolution Malaysian batik art form have not comprehensively covered the development of contemporary Malaysian batik industry, believed to be founded circa 1920s. Earliest activities are clustered around the "hand-drawn" variants of design, which enables local jobs and business opportunities in rural areas, while encouraging entrepreneurship that helps boost tourism performance [6].

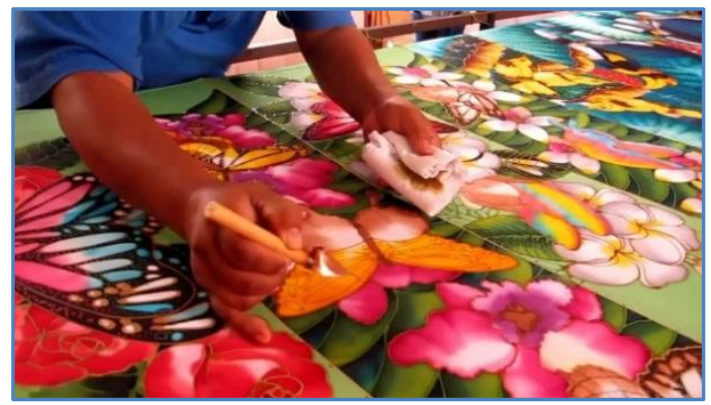

Figure 1. Malaysian batik painting [17]

The batik sarong is inextricably linked to the local cultural orientation that identifies Malay heritage; its enduring presence as an ethnic costume comes from the inimitable designs applied using wax from the metal block (cap), a procedure believed to have been copied from north Javanese designs, but gradually evolving into unique Malaysian motifs, with the pucukrebung (bamboo shoot) as the prominent element, with the Islamic preference for geometric and denaturalised stylisation [1]. Metal block stamping became the main production tool from 1960s, developing the characteristic batik cap schemes and patterns which are block-printed into items of clothing other than the sarong [1]. Canting, a key applicative instrument is the flexible stylus used to apply liquid wax in traditional batik handicraft, also known as batik tulis.

\subsection{The Roots of Batik}

The word 'batik' was derived from the Javanese word meaning wax writing. It was based on the process of resist, which was known to be an ancient method of applying design to porous surfaces [7]. Parts of the fabrics are covered with melted wax, rice, paste, and some other non-water dissolve substance and the fabric is later submerged in, or painted with, various colours of dyes [5]. The exact origin of batik is unknown, but thought to have existed for over 35,000 years, used ubiquitously among Austronesian communities living in Southeast Asia, with applications on woven cloths similar to tie-dye methods, to resemble resist patterns such as ikat, plangiand tritik [2: 15]. 
In Southeast Asia, the Javanese embraced resist crafts as their own: naming the designs and shifting its usage from royalty-reserved embellishments into a communal cultural craft, the form of which is known today [8: 12-14; 9]. Java Island is a natural confluence and assemblage point of coastal and inland communities, but no record of artisanal output documents the transfer of knowledge and skills involved in wax-resist techniques to peninsula Malays [5]. Javanese batik grew in popularity from early $19^{\text {th }}$-century through Islamic designs exported from northern Java to Muslim clientele [1: 25]. Peninsula Malays later developed two main styles: symmetrical geometric motifs and flowing freehand patterns [8: 15].

\subsection{Batik as aMalaysian Cultural Icon}

Yulo [2: 11], researching on the interrelation of history and character of societies, found that ancient cultures reflect the diversity of experiences of their communities, while traditional arts and crafts disclose a composite of historical events and their surroundings, some of which bear spiritual significance.

In anthropology and sociology, batik's role as an art form is often discussed through its variable patterns, shapes and design elements. Malaysian batik, although considered as a traditional Malay craft, is less than a century old [10]. Its aesthetics defines and characterises the heritage of the Malays, seen through motifs which blends the Malay sultanate culture, community values, imagination and creativity in interpreting their surrounding environment meaningfully [4: 100-102].

Malaysia's batik design heritage, seen in a modern context, is premised on its dynamic sociocultural capacities to serve markets, yet these decisions are often in the broader interests of government economic agendas. As Leigh [4: 96] explains, "(the) leaders of the Malaysian state (and through them, the producers of Malaysian batik) are ... proactive players in the production of material cultural identities."

Leigh [4] argues that "non-market forces" such as affirmative actions and state intervention underlie the promotion and protection of the Malay-dominated cultural production sectors, seen through the government's active, consistent and significant support of batik and pewter; thus, these highly commercialised goods are today imbued with socioeconomic value as much as they bear the weight of cultural identity images.

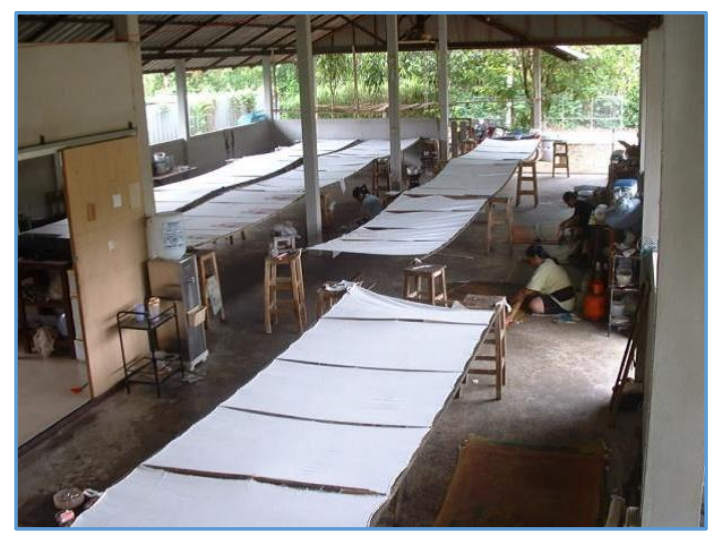

Figure 2. Batik silk printing factory [18]

Noor Azlina [1] states that batik's perpetuity is due to a broadening of its branding perceptions, from being "less a craft (to) more of an art". Being a few decades old puts it in an advantageous position for its image rebranding as an 'elite' art form. Innovation centred on creating new markets has also contributed to the industry's survival. By cultivating batik as a form of fine art, as well as diversification of its brand image as chic couture, works by batik artisans and designers are recognised for their uniqueness and elegance.

Yet a number of industry challenges have arisen. Imports from China and Indonesia are both competitive and equally accessible [11], as mass-produced printed textiles flood markets in substitution for more expensive hand-painted batik (Figure 2). Leigh [4: 103] also points out the importance of having a domestic market that could buffer against fluctuation of demands, while Dewilzzwi [3] believes it is vital to strengthen the industry players' entrepreneurial orientation 
through increasing reputation, capital and marketing capabilities in order to generate employment and in particular, help sustain the economic growth of Malaysia's east coast states of Kelantan and Terengganu.

\subsection{Formal and Informal Wear}

Formal wear framed on batik fashion (Figure 3) parallels the dichotomy between traditional and nontraditional. Formal women's wear is heavily weighted towards adaptations of traditional Malay clothing such as bajukurung, baju Kedah, bajukebaya and bajumoden, considered as appropriate garments for evening and formal functions, especially favoured by designers if tailored in silk [12]. Batik gowns, both long and short, are popular formal wear for both Malays and non-Malays and feature regularly in competitions. As more ready-to-wear clothing in contemporary styles become available, the younger clientele are showing keen interest to buy off-the-peg attire instead of tailored styles [1].

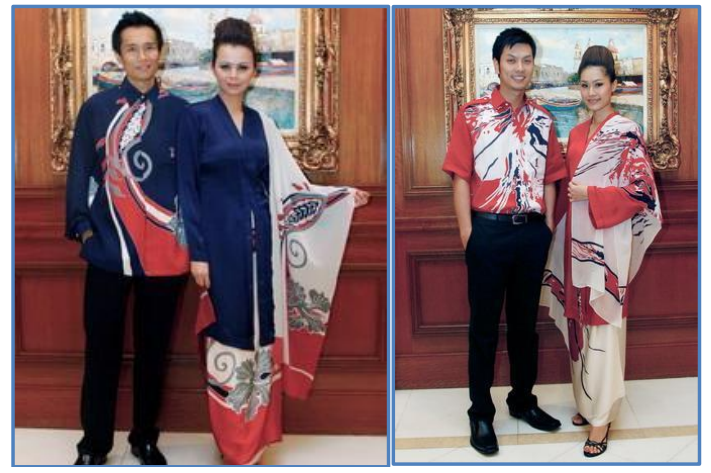

Figure 3. National Batik Attire [19]

Batik lends itself beautifully to casual wear: wraparound sarongs, dresses and tops, loose palazzo pants, pareos and caftans. Modest fabrics and headscarves for Muslim women are also a batik staple among contemporary fashion designers. Many of the motifs on the hand-drawn batik (batik tulis) designed for informal wear are significant [1]. Many of Malaysia's upcoming as well as established designers strive for the right blend in between the traditional forms and fabrics of their rich culture with contemporary lifestyles.

\subsection{Current Trends}

Modern batik artisans have been exploring the range of creative processes ever since batik's pioneering establishments. The use of hot liquid colour to decorate a piece of undyed cloth, has changed through improvements in fabric technology, printing techniques and fashionable styling, all contributing to its couture expressiveness (Figure 4), stimulating creativity and resourcefulness in the treatment of the wax-resist process [6].

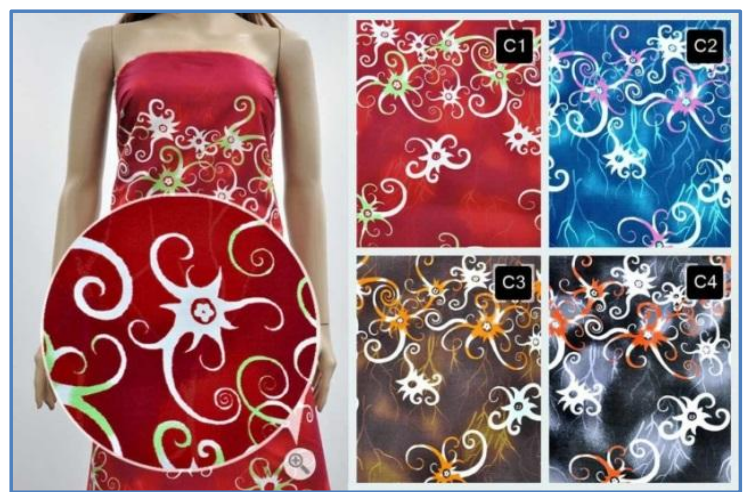

Figure 4. Modern batik design patterns [20]

Contemporary batik is markedly different in its presentation styles. Designers are no longer constrained by the straightforward metal block stamping of patterns: silk screen, screen printing, etching, scrafitto, stencilling, rollers and spray guns are both acceptable and efficient steps for design application. Canting (batik tulis) is still the most enduring and authentic form of wax application, but contemporary batik artists work equally comfortably on linen, denim, wool, leather, paper, wood and ceramics, in addition to cottons and silks. 
Dyeing, once done using the dipping and brushing method, can now be performed by bleaching, spraying and splattering. Yet, for Malaysia, the new wave popularity of wax-resist techniques in hand-drawn silks, as well as the application of beads and sequins for added glamour, has inadvertently triggered many artists' wish to experiment using traditional block-printing (batik cap) as well as to explore traditional batik crafting process [1].

\subsection{Batik in Contemporary Fashion}

The fashion system is an essential part of symbolic innovation. It consists of people and organisation involved in creating symbolic meanings and transferring these meanings to cultural goods [13]. In Malaysia, the development of batik fashion follows two trajectories: traditional and non-traditional.

Traditional designs followed a fixed direction across the weft; and with no repeated patterns, the cutting and tailoring of sarongs into other types of garments was a difficult task. The use of batik in non-traditional fashion did not begin until 1960s, when metal wax-stamping (batik cap) cotton yardage was cut and sewn into Western-style dresses, blouse, skirts, short-sleeved Hawaiian-inspired shirts, matching sarongs and bajukebaya. The handcrafted fabric was considered quite revolutionary at the time.By the 1970s, stylus batik (batik tulis) was applied successfully in the hope of penetrating mass consumer markets [1].

A social welfare and educational foundation, Yayasan Budi Penyayang (Penyayang) fired the scene in order to revitalise the batik industry. Diversification was the new ethos considered essential for industry sustenance, and the strategic development of batik as a contemporary fashion fabric was aimed at middle and upper markets [1]. Some of the surprising designs included sarong-and-tunic and caftan combinations for women and long-sleeved shirts for men. Despite initial challenges adapting to silky fabrics [12], each successive generation of designers developed sumptuous and original patterns to appeal to these class segments, ultimately setting the taste for urban consumers to perceive batik's elitist image.

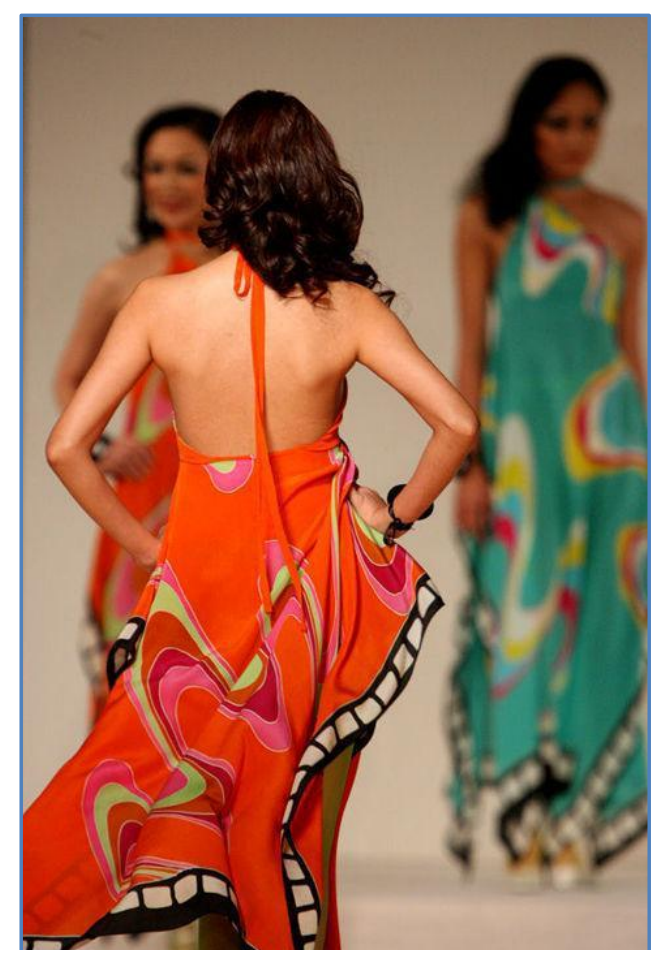

Figure 5. Contemporary batik dress [21]

A two-pronged approach resulted in batik's adaptation into modern fashions, while local designers branded it as high fashion couture to augment its beauty. In 2003, Penyayang initiated Piala Seri Endon (Seri Endon Trophy, named after the organisation's first chairman, TunEndonMahmood, late wife of Malaysia former prime minister, Tun Abdullah Ahmad Badawi), an annual national competition to promote batik design. Both Piala Seri Endon and the Terengganu Piala Seri Iman 
have been enormously successful in inspiring innovation in design, encouraging use of new materials and production technology [1].

Contemporary batik fashion (Figure 5) has benefitted greatly from the involvement of Malaysian fashion designers, some who are recognised in domestic markets, while others produce solely for international fashion events, thus widening commercial access to batik [1]. Additionally, numerous innovative techniques have been a key tenet driving the industry. For instance, experimentations with eco-friendly dyes, non-toxic wax, double layer canting and other creative fusion fashion concepts enables batik designers and entrepreneurs to differentiate their goods, and seek both educate and widen acceptance for handmade products that are viable for mass customisation [1: 10]. The arts handicrafts and souvenir industries, on the other hand, are constantly challenged to exploit batik themes in their promotional initiatives for the tourism industry [4].

\subsection{Batik as Lifestyle}

Since the 1960s, Malaysian batik has evolved into a multifunctional fabric. It rapidly became a versatile yet affordable decorating material for professional interior designers and homemakers alike. The emphasis, however, was on lifestyle products that could be cut from cotton batik yardage or hand-drawn to size on silk rather than on the production of batik as a furnishing or upholstery fabric.

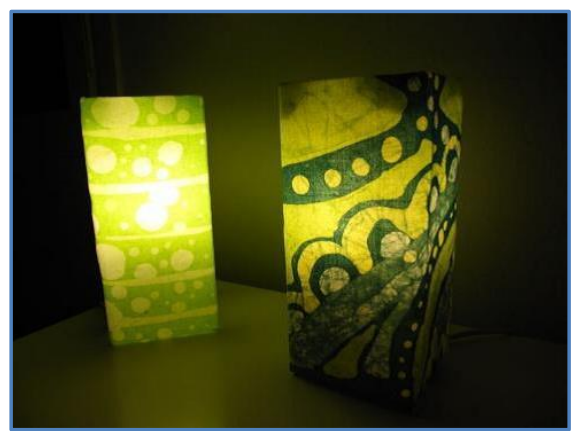

Figure 6. Batik lamp shades [22]

What some perceived as nothing more than women's sarong wear was upturned after the introduction of batik cap yardage in the 1960s and the application of batik tulis in the 1970s - the latter seen as the most effective strategy for long term industry, since it could be executed relatively quickly but was yet unique and inimitable. Batik thus expanded its traditional boundaries of use as clothing to decorative items for the home and furnishings for the hospitality sector. Encouraged by the Malaysian Handicraft Development Corporation (Kraftangan), batik manufacturers in east coast Peninsula states modifying old patterns and creating new ones to accommodate usage for a range of decorative items, as stamped cloth yardage were produced for table linens, bed linens, cushion covers and household items, such as photo frames and wallets (Figures 6 and 7), and larger items such as wall hangings. Batik is also ideal for gift-giving: gift wrapping in batik-patterned paper grew as a genuine way of promoting Malaysian batik to the world.

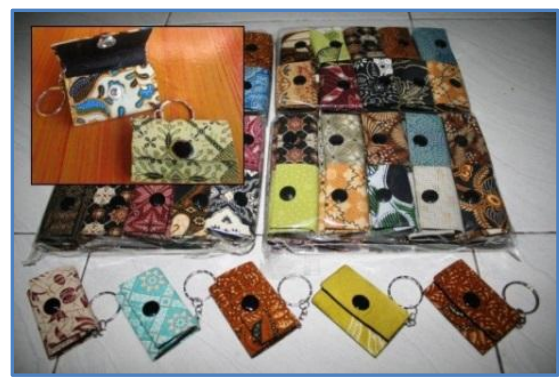

Figure 7. Batik Souvenirs [23]

\subsection{Soft Furnishings}

Syarikat PemasaranKaryaneka (Karyaneka) is the marketing subsidiary for Kraftangan responsible for marketing handicraft and decorative souvenirs which reflect Malaysia's ethic origins, inspirations and cultural heritage [1: 107]. To boost Kraftangan's promotion of batik usage for furnishings, apart 
from widening batik's scope of creative uses in fashion, Penyayang added the soft furnishing category to the Seri Endon Cup competition in 2004. Healthy participation from interior decorators and young designers has resulted, despite being viewed as the most challenging category of the competition. This initiative has enabled Penyayang to set up a gallery of local batik artisans' work, showcasing new and bold ideas [14], while giving opportunities for young talent for broadening their exposure, and enabling the industry to "breed the best" [15].

\section{Methods AND Procedures}

Based on the research objectives, both quantitative and qualitative methodologies were decided to be the instruments of research as sequential explanatory mixed methods. A questionnaire was designed to measure a sampling of respondents' awareness and perceptions about thepotential of Malaysian batik. An interview was also conducted with a designer and entrepreneur in the batik field.

\subsection{Questionnaire}

Using quantitative methods, a questionnaire was constructed consisting 13 questions to obtain information regarding respondents' perceptions towards batik, its brand identity and cultural value from contemporary perspectives. Questions were designed and aimed at gathering data to inform the process of investigating batik's current and future potential through evaluating the aesthetic, cultural and socioeconomic values of local batik. These questionnaires were distributed to four different universities in Malaysia, consisting two private universities and two public universities. 100 responses were successfully collected for data analysis, with no unusable responses.All respondents are Malaysian citizens, aged 18 to 25 years. The age samples of respondents are appropriate in determining the perceptions of this age segment towards batik as a cultural art form.

\subsection{Interview}

Industry participation was essential to enable more accurate representation of local insider insights towards the subject.A set of interview questions was designed to probe the practitioners' perceptions through wealth of experiences and perspectives towards Malaysian batik, as well as suggestions to move the industry forward.

To obtain direct knowledge and business insights about the batik industry, several interviews were planned. Due to various practitioners' time constraints and commitments, only one participant was available. Nevertheless, with the application of mixed methodologies of research, the insights gained in this study through the interview can be considered critical.

\section{RESUlTS AND DISCUSSION}

Based on the survey conducted, out of 100 random samples of respondents consisting 50 males and 50 females, their knowledge on batik is considered moderate. Chart 1 shows that $72.73 \%$ of respondents like batik products because of its colourful motifs, $60 \%$, its cultural history and heritage, $56.36 \%$ because it represents the Malaysian identity, while the remaining $7.27 \%$ chose its unique design as the reason for liking batik.

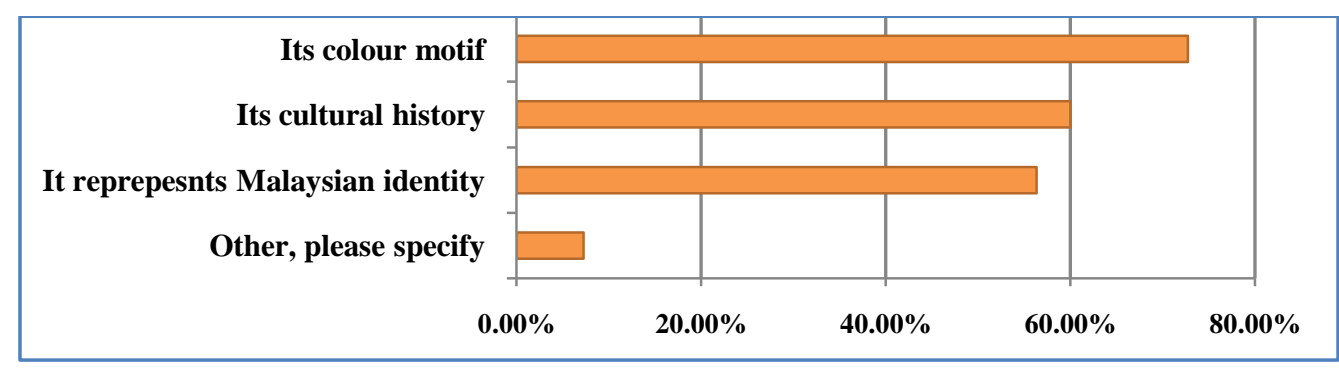

Chart1

The question of factors affecting Malaysians' understanding of batik followed. As shown in Chart 2, $69.09 \%$ of respondents of both genders thought that Malaysian batik lacks points of interest as a part of culture, followed by lack of relevance $(58.18 \%)$, lack of historical knowledge $(29.09 \%)$, and the remaining $1.82 \%$ perceived batik art to be mainly for women. 


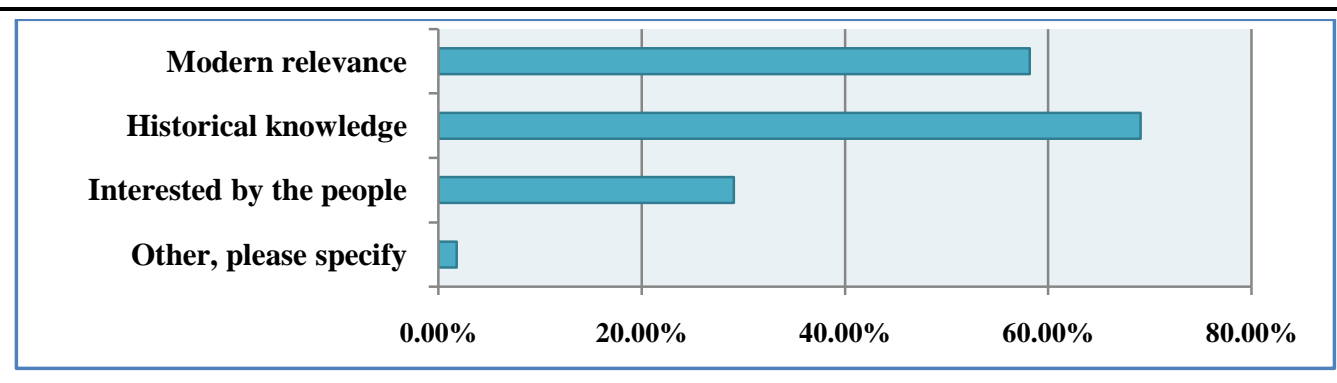

Chart2

Regardless the lack of interest, as shown in Chart 3, the majority of respondents with $50.91 \%$ still believed that batik art has not vanished, most likely from its regular appearance at official functions in the government sectors, during special occasions, traditional festivals or even weddings. Chart 3.1 and 3.2 show the respective perceived reasons for why respondents thought batik was attractive as part of contemporary fashion and lifestyles.

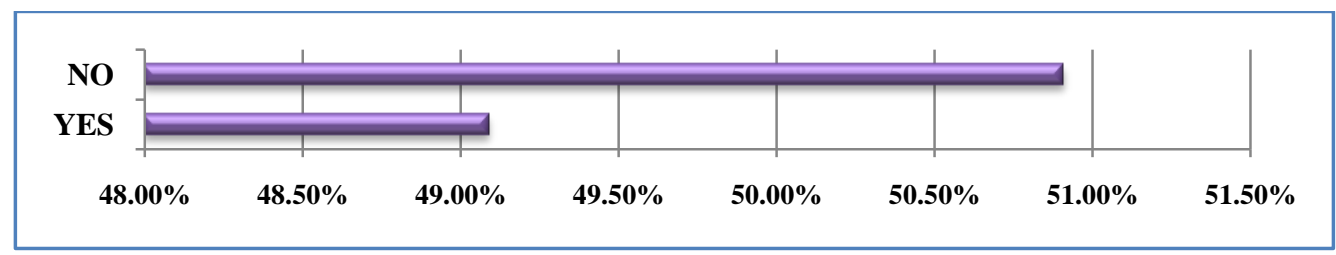

Chart3

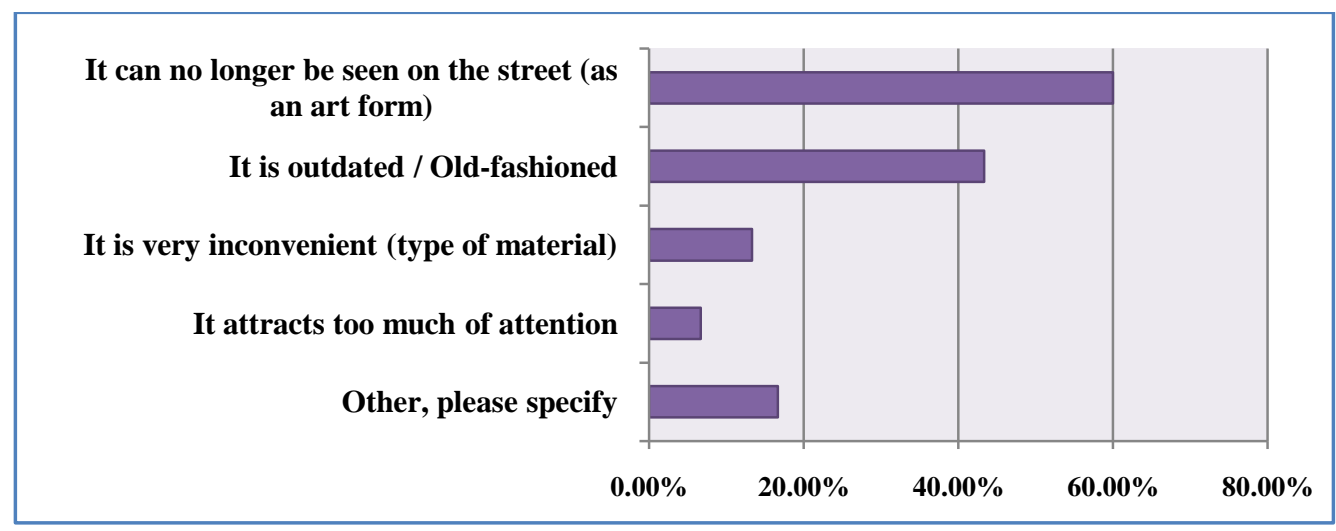

Chart3.1

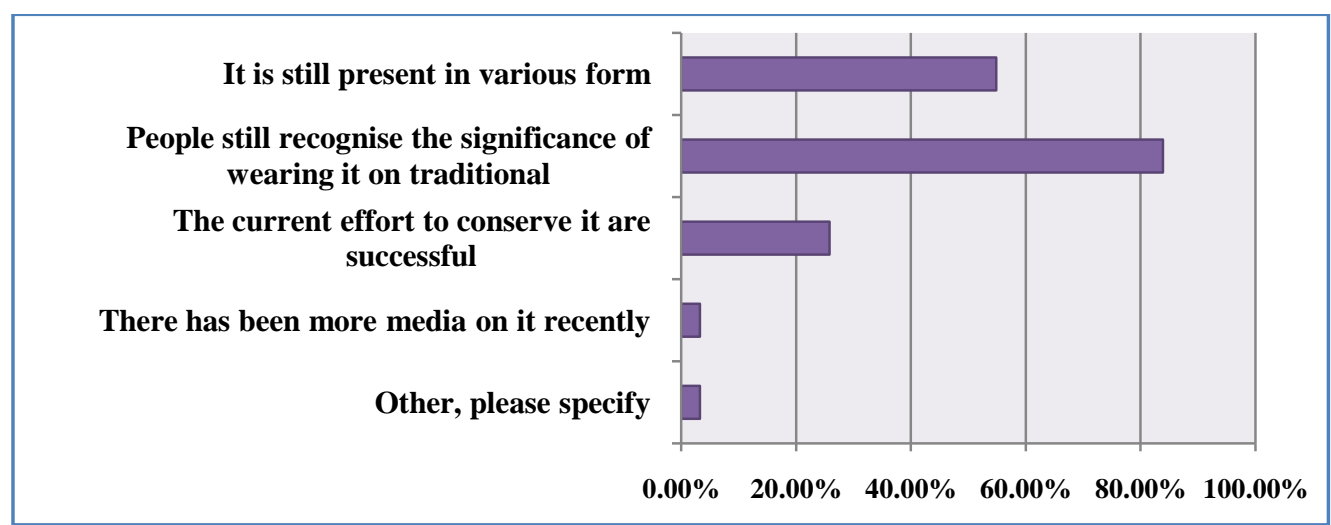

Chart3.2

In terms of the price value, the researcher has found out that, majority of the respondents are willing to spend at the range of RM50-RM99 (Malaysian Ringgit) for batik attire such as men's short or long sleeves shirt and women's bajukebaya. Queried on their main reason to purchase batik, most respondents answered it was the unique patterns and design (Chart 4). On marketing strategy, factors such as quality, design and pricing were crucial determinants for the continued flourishing of the Malaysian batik industry locally and globally.This is inferred from responses shown in Chart 4, as $74.54 \%$ respondents rate design as their most important factor in choosing batik products, followed by 
The Journey to Revival: Thriving Revolutionary Batik Design and its Potential in Contemporary Lifestyle and Fashion

quality at $60 \%$, pricing at $47.27 \%$, broad selection at $23.64 \%$, and the remaining $5.46 \%$ for recognised brand name.

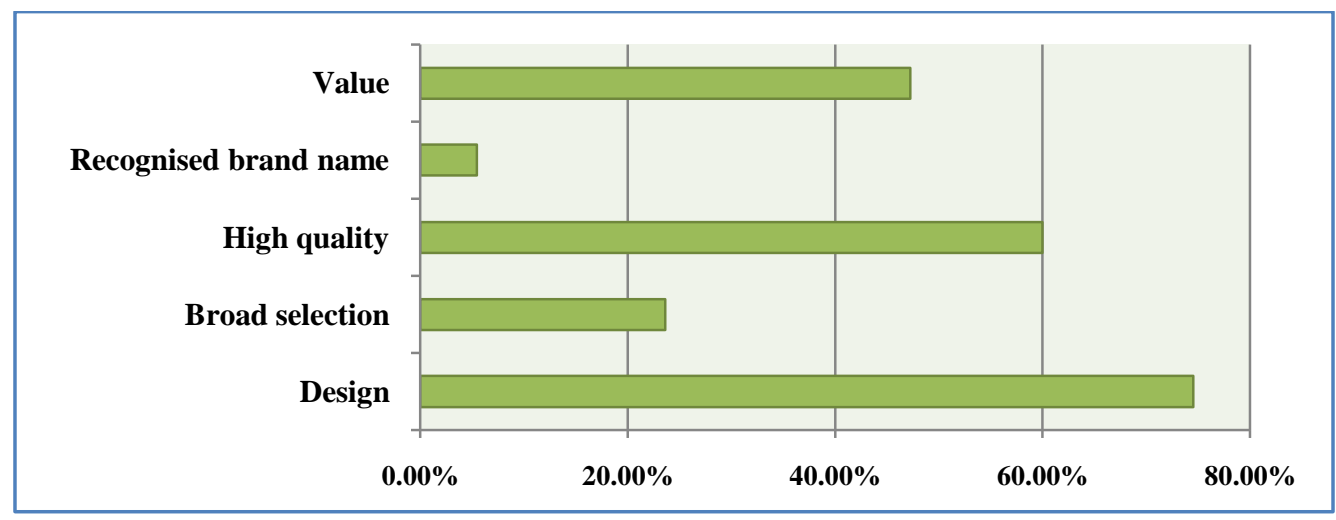

Chart4

Apart from that, respondents were asked on legitimate methods to promote and influence social attitudes towards batik. Chart 5 shows that well-trained sales or service agents, trade shows and fashion or lifestyle events, online advertisements and commercials (41.82\%) are thought to be equally valuable and important methods in influencing consumers, followed by local publications at $38.18 \%$.

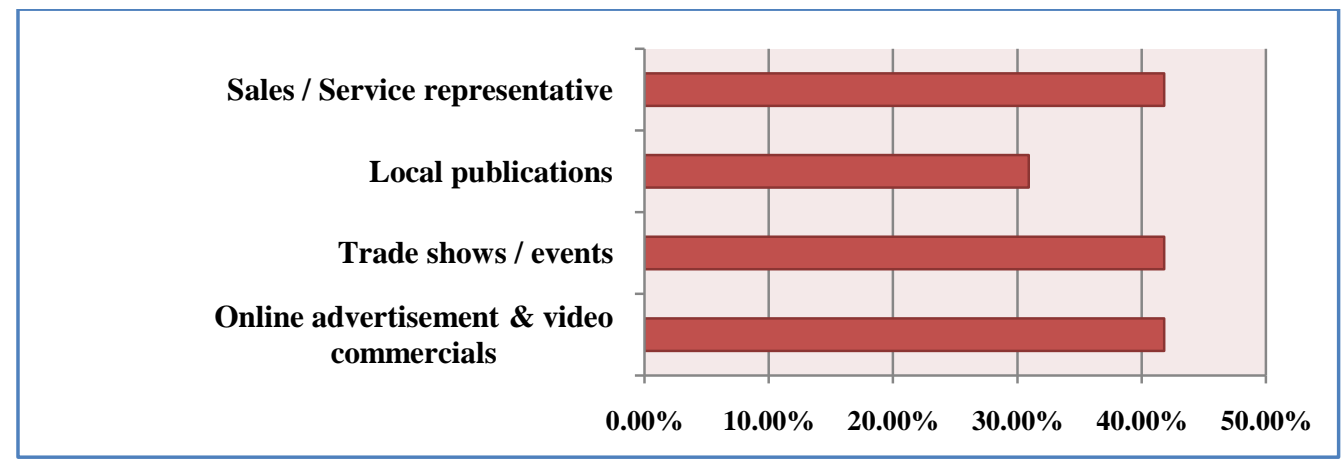

Chart5

The respondents were asked whether incorporating Malaysian batik motifs into western fashion would be culturally conflicting, and many thinks it depends on the execution. Some believe the fabric's representation of traditional and cultural heritage would help local social identification. Collaborating with western fashion would impact on the local culture. It is evident that it will potentially be beneficial, serving as an emblematic art form to broaden Malaysia's economic and cultural influences.

The next question consisted of two components: first, to understand the level of awareness of respondents towards Malaysian contemporary batik design industry; and second, whether batik elements should be incorporated into fashion or products today. Results of the first part (Chart 6) informed that a slight majority of 56.36\% were unaware.However, the majority of 94 respondents out of the total sample of 100 agreed with the concept of incorporating batik in contemporary fashion or products. This result supports the first hypothesis that incorporation of Malaysian Batik into contemporary fashion or products can increase and stimulate interest among consumers.

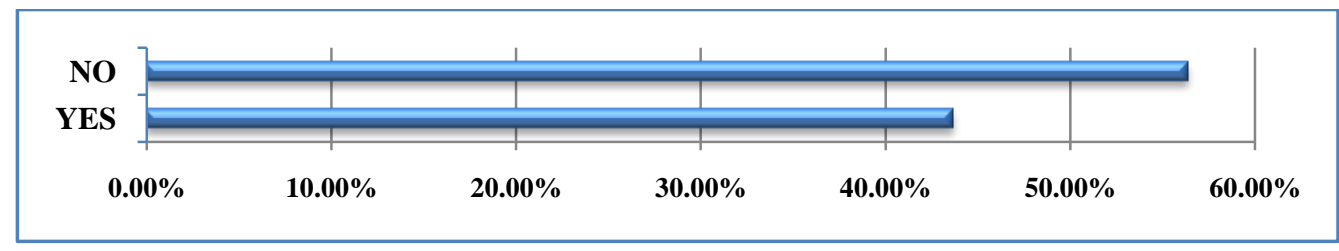

Chart6

The final question involved a scale ranking of six options to understand respondents' perceptions of, and potential interest in, Malaysia batik. The results were tabulated below. 


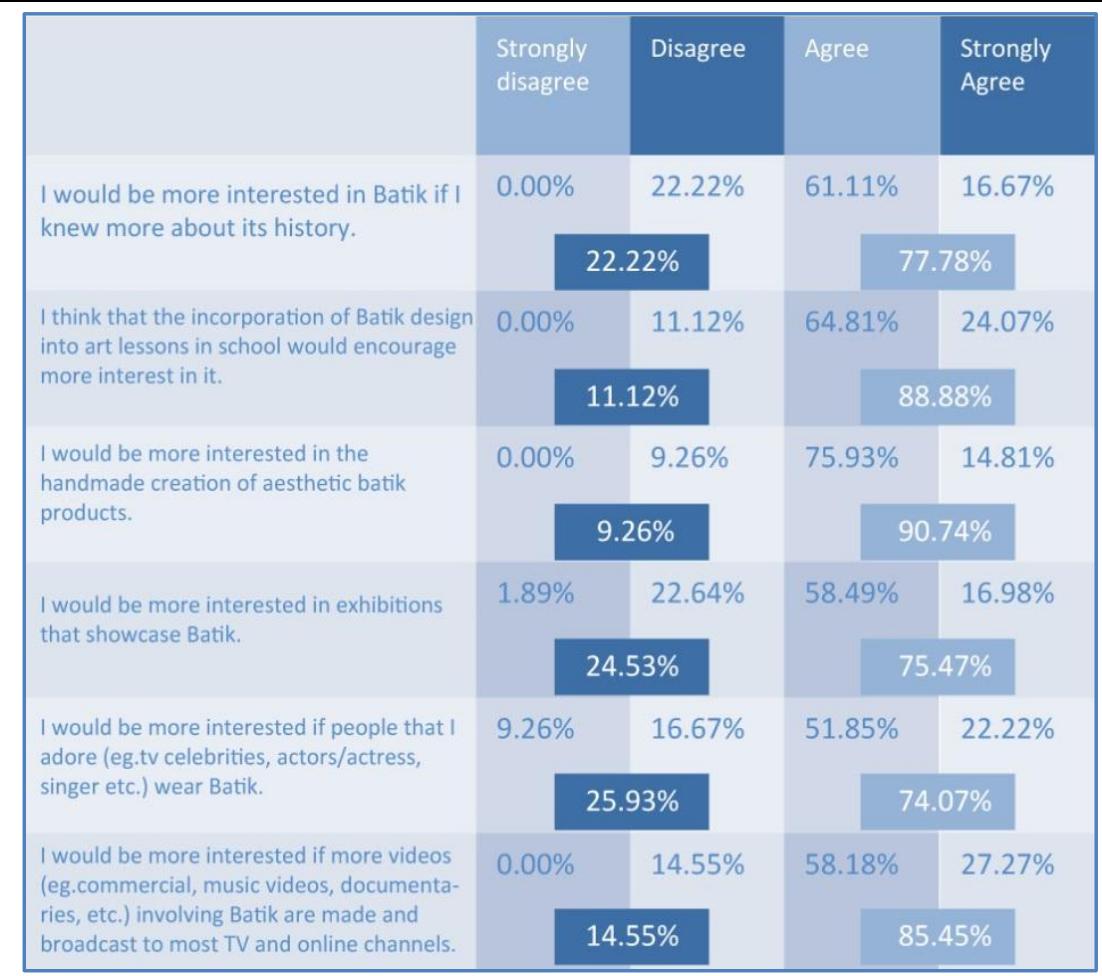

Table1

Based on Table 1, 88.88\% respondents stated that through incorporating batik design into art lessons in school, greater interest would be shown among students. The majority $(90.74 \%)$ agreed that the aesthetic of batik lies in the handmade creations rather than mass-produced variants. Another noteworthy finding was that $85.45 \%$ of respondents agreed the use of media communication such as video commercials, music videos, documentaries and online channels can be leveraged as batik's marketing and promotional platforms. From the results, the second hypothesis, consistent branding of Malaysian Batik through online media and other interactive communication platforms stimulates consumer interest and engenders loyalty is thus validated.

\subsection{Interview}

The interviewee, DeenHj. Samsudin is a veteran batik producer as well as batik entrepreneur originating from Kelantan. He stressed the importance of the cloth in daily lives. "[Batik] has turned into many mediums and has different usages, from fashion and accessories to decoration. It has even been adapted into items such as soft toys, cushion and pillow covers, lamp shades, and other interior decorative furnishings".

Deen reiterated the common past belief that the cloth was solely used for women's clothing. "Although some were made for men, the focus was more towards women. However, in the present day, batik has become more universal as most products gain a market foothold. Exports of batik products help stabilise the demand of the fabric among markets, for example France, Italy, Germany, England and other countries".

He notes that the current level of market penetration for Malaysian batik has been due to a mix of consistent branding initiatives by Yayasan Budi Penyayang internationally, but that small-time producers could only serve domestic demands as "simply did not have the resources - capital, expertise and time" necessary for expanding their businesses. This accords with a 2014 study that inexperienced batik entrepreneurs would lack business skills to be able to compete effectively [16].

Deen believes batik produced manually is more authentic: "Both sides of the plaids have the same colour compared to the ones made by machines where one side of the plaid will have low saturation of colour". This usually determines the pricing, as mass-made products are likely to be much cheaper. "Handmade batik has to account for specialised skilled labour and service costs. Hence, it is not possible to conclude that design determines the price of a batik product. Rather, its value lies in the steps taken in its manufacture". 
As for growth strategy, Deen believes the annual increase in the number of students in vocational institutes and design colleges enables the demands of the market and creative sectors to be fulfilled, which expands the industry while enabling innovators to gain training and exposure in order to revolutionise batik in ways that suits contemporary design sensibilities and needs. "The concept of contemporary design is essential to pique the interest of today's generation. Since our ancestors managed to create something that was so beautiful, the young generation can preserve the motifs with a little bit of modification in order to adapt this art to our present environment".

\section{CONCLuSiON}

This paper sought to represent the brand identity of Malaysian batik design as an art form that has developed tremendously from its inception as cultural clothing of traditional Malay communities. Innovative crafting and design techniques have expanded its potential ability to serve different markets. Ultimately, understanding its heritage and aesthetic value as a handmade craft would result in added appreciation for the artisans, skills and accomplishments of material culture that has evolved this modest craft form into a functional, yet no less enchanting, modern cultural objet d'art.

Research data demonstrated overwhelming concurrence that handmade batik outshone mass-produced variants.However, it is inevitable that handcrafted batik will suffer with competition from modern technology. Some craftspeople view the mechanised, mass production of textiles as a corrupting factor; nevertheless, most Malaysian practitioners agree that working along with, rather than against, adaptation of batik's authentic form into modern designs is the way for strategic growth. Alternately, by viewing technology as an enabler, it could contribute to future brand identification of the form. While machine production can never duplicate the fluidity of handmade batik, it nevertheless helps foster cultural education, awareness and appreciation of its value. There is thus no question of dismissing technology.

This study shows Malaysian batik's versatility in adaptation for contemporary attires, furnishings and commercial fashion, without losing its authenticity as a shared medium of social expression. Survey respondents' acknowledgement of batik as a suitable form of official wear for formal events and special occasions, other than symbolising Malaysian culture and tradition, gives a directional hint for the future, as one that lies somewhere between developing keen followership and admiration for its purist forms, and finding new avenues of expansion through contemporary craftwork, design and marketable fashion.

The success of Piala Seri Endon has boosted industry confidence to explore creative avenues, and to embrace batik practitioners of all ages, experience and creative thinking, thus blending Malaysian batik designs into contemporary lifestyles. This will establish new frontiers for the local batik industry to thrive. From primary research and literature resources, it can be concluded that the most concerned stakeholder in ensuring success of future initiatives and projects would be the Malaysian government, and that promotional mechanisms are to be initiated at national and state levels to enhance awareness of Malaysia's brand of batik to institutions, visitors and dignitaries, which were alike [4: 103]. Contemporary design crafting necessitates collaborations between pioneers and professional practitioners; the outcomes of which can be proposed to entrepreneurs, fashion houses, entertainment media and event managers for ceremonial events, performances, documentaries, features and other forms of visual media. Besides creating awareness, such effort draws forth batik's potential by giving strong impetus among the young generations to experiment, develop and sustain the construction of its aesthetic, cultural and socioeconomic identities in the coming decades.

\section{REFERENCES}

[1] Noor Azlina Y. Malaysian Batik Reinventing a Tradition. Singapore: Tuttle Publishing; 2011.

[2] Yulo EC. Awesome Austronesians: The Austronesian Origins of Tie-Dye (Ikat) Weaving. [Conference Paper] 13 $3^{\text {th }}$-International Conference on Austronesian Linguistics. 17 January. Taipei: Institute of Linguistics, Academia Sinica\& Linguistic Society of Taiwan; 2015.

[3] DewiIzzwiAM. The Influence of Internal Resources and Entrepreneurial Orientation on the Performance Satisfaction of Batik Firms in Malaysia. [PhD Thesis] Faculty of Business Management, UniversitiTeknologi Mara; 2012. 
[4] Leigh B. Batik and Pewter: Symbols of Malaysian Pianissimo. Sojourn: Journal of Social Issues in Southeast Asia, 2002; 17(1), April: 94-109.

[5] Elliott IM. Batik, Fabled cloth of Java. $2^{\text {nd }}$ ed. Singapore: Periplus; 2004.

[6] Wan Hashim WT. Malay Handicraft Industries: Origins and Development. Kuala Lumpur: DewanBahasa\&Pustaka; 1996.

[7] Dyda Cactus. Batik. 12 October 2012. Blog. Available from:http://dydacactus.blogspot.my/ 2012/10/batik.html [Accessed 20 January 2017].

[8] Piper E. Batik for Artists and Quilters. Tunbridge Wells: Search Press; 2001.

[9] Smend RG, Majlis BK, Harper DJ, Veldhuisen HC and Wenger P. Batik from the Courts of Java and Sumatra. Singapore: Periplus; 2004.

[10] Arney S. Malaysian Batik: Creating New Traditions. Kuala Lumpur: Malaysian Handicraft Development Corporation; 1987.

[11] Ab Kareem S. The Business of Batik Proceedings 2005. Selangor: MPH Publishing; 2007.

[12] Stokoe S. Silk Painting \& Batik. London: Southwater Publishing, 1999.

[13] Solomon M. Consumer Behavior. $4^{\text {th }}$ ed. Upper Saddle River, N.J.: Prentice Hall; 1999.

[14] Penyayang. Galeri Seri Endon. Available from: http://www.penyayang.org.my/galeriseriendon.php [Accessed 24 ${ }^{\text {th }}$ November 2016].

[15] Halimah MS. Malaysian Batik: A Tradition Comes of Age. The Star Online. 23 December 2011. Available from: http://www.thestar.com.my/lifestyle/books/2011/12/23/malaysian-batik-atradition-comes-of-age/ [Accessed $20^{\text {th }}$ December 2016].

[16] Nair N. A Boost for Batik. The Star Online. 26 September 2014. Available from: http://www.thestar.com.my/news/community/2014/09/26/a-boost-for-batik-designers-work-liftsprofile-of-traditional-fabric/ [Accessed $5^{\text {th }}$ November 2016].

[17] Figure 1: Malaysian Batik Painting. Nyström J. The Malaysian master of batik painting is creating a work of art. 30 May 2013. Langkawi Craft Center.YouTube.Available from:https://www.youtube.com/watch?v=DXoP3HwqPnk[Accessed 5thDecember 2016].

[18] Figure 2: Batik Silk Printing Factory. Fisherman Pants. 2012. Batik Area. Available from: http://w489.photobucket.com/albums/rr257/shmargad/batik5-1.jpg [Accessed $16^{\text {th }}$ January 2017].

[19] Figure 3: National Batik Attire. Rmreview.Malaysia 53 ${ }^{\text {rd }}$ Independence Day Batik Attire. 2010. Available from: http://rmreview.com.my/wp-content/uploads/2010/07/MALAYSIA-53rdINDEPENDENCE-DAY-BATIK-ATTIRE-1.jpg [Accessed $1{ }^{\text {st }}$ December 2016].

[20] Figure 4: Modern Batik Design Patterns. Kamdar.Printed Exora Malaysia Batik Cotton Collection. Available from: http://www.kamdaronline.com/images/4325001d_popupimages.jpg [Accessed 12 ${ }^{\text {th }}$ November 2016].

[21] Figure 5: Contemporary Batik Dress.Chong P. Malaysian Batik in Fashion. Available from: http://www.mir.com.my/rb/photography/hardwares/classics/eos/EOS-1n/creditimages/Philip_Chong/Fashion_show.JPG [Accessed: $23^{\text {rd }}$ December 2016].

[22] Figure 6: Batik Lamp Shades. Akka design.Batik Lamps. 2010. Available from: http://p8.storage.canalblog.com/88/80/588046/49386085_p.jpg [Accessed $5^{\text {th }}$ January 2017].

[23] Figure 7: Batik SouvenirsElmyda. Batik Coin Purse Keychain Suitable For Gifts \& Souvenirs. 2002. Available from: http://76.my/Malaysia/batik-coin-purse-keychain-suitable-giftssourvenirs-elmyda-1007-31-elmyda@13.jpg [Accessed $16^{\text {th }}$ December 2016]. 